\title{
Some New Carbacylamidophosphates as Inhibitors of Acetylcholinesterase and Butyrylcholinesterase
}

\author{
Khodayar Gholivand ${ }^{\mathrm{a}, *}$, Ahlam Madani Alizadehgan ${ }^{\mathrm{a}}$, Fresia Mojahed ${ }^{\mathrm{a}}$, \\ Gholamreza Dehghan $^{\mathrm{b}}$, Azadeh Mohammadirad ${ }^{\mathrm{b}}$, and Mohammad Abdollahi ${ }^{\mathrm{b}}$ \\ a Department of Chemistry, Faculty of Sciences, Tarbiat Modarres University, \\ P. O. Box 14115-175, Tehran, Iran. E-mail: gholi_kh@modares.ac.ir \\ b Laboratory of Toxicology, Faculty of Pharmacy and Pharmaceutical Sciences Research \\ Center, Tehran University of Medical Sciences, P. O. Box 14155-6451, Tehran, Iran \\ * Author for correspondence and reprint requests \\ Z. Naturforsch. 63c, $241-250$ (2008); received August 15/September 17, 2007
}

The differences in the inhibition activity of organophosphorus agents are a manifestation of different molecular properties of the inhibitors involved in the interaction with the active site of enzyme. We were interested in comparing the inhibition potency of four known synthesized carbacylamidophosphates with the general formula $\mathrm{RC}(\mathrm{O}) \mathrm{NHP}(\mathrm{O}) \mathrm{Cl}_{2}$, constituting organophosphorus compounds, where $\mathrm{R}=\mathrm{CCl}_{3}(\mathbf{1}), \mathrm{CHCl}_{2}(\mathbf{2}), \mathrm{CH}_{2} \mathrm{Cl}(\mathbf{3})$ and $\mathrm{CF}_{3}(\mathbf{4})$, and four new ones with the general formula $\mathrm{RC}(\mathrm{O}) \mathrm{NHP}(\mathrm{O})\left(\mathrm{R}^{\prime}\right)_{2}$, where $\mathrm{R}^{\prime}=$ morpholine and $\mathrm{R}=\mathrm{CCl}_{3}(\mathbf{5}), \mathrm{CHCl}_{2}(\mathbf{6}), \mathrm{CH}_{2} \mathrm{Cl}(\mathbf{7}), \mathrm{CF}_{3}(\mathbf{8})$, on $\mathrm{AChE}$ and $\mathrm{BuChE}$ activities. In addition, in vitro activities of all eight compounds on $\mathrm{BuChE}$ were determined. Besides, in vivo inhibition potency of compounds $\mathbf{2}$ and $\mathbf{6}$, which had the highest inhibition potency among the tested compounds, was studied. The data demonstrated that compound $\mathbf{2}$ from the compound series $\mathbf{1}$ to $\mathbf{4}$ and compound $\mathbf{6}$ from the compound series $\mathbf{5}$ to $\mathbf{8}$ are the most sensitive as AChE and $\mathrm{BuChE}$ inhibitors, respectively. Comparing the $\mathrm{IC}_{50}$ values of these compounds, it was clear that the inhibition potency of these compounds for AChE are 2- to 100-fold greater than for BuChE inhibition. Comparison of the kinetics ( $\mathrm{IC}_{50}, K_{\mathrm{i}}, k_{\mathrm{p}}, K_{\mathrm{A}}$ and $K_{\mathrm{D}}$ ) of $\mathrm{AChE}$ and $\mathrm{BuChE}$ inactivation by these compounds resulted in no significant difference for the measured variables except for compounds $\mathbf{2}$ and $\mathbf{6}$, which appeared to be more sensitive to AChE and BuChE by significantly higher $k_{\mathrm{p}}$ and $K_{\mathrm{i}}$ values and a lower $\mathrm{IC}_{50}$ value in comparison with the other compounds. The $\mathrm{LD}_{50}$ value of compounds $\mathbf{2}$ and $\mathbf{6}$, after oral administration, and the changes of erythrocyte AChE and plasma BuChE activities in albino mice were studied. The in vivo experiments, similar to the in vitro results, showed that compound $\mathbf{2}$ is a stronger $\mathrm{AChE}$ and $\mathrm{BuChE}$ inhibitor than the other synthesized carbacylamidophosphates. Furthermore, in this study, the importance of electropositivity of the phosphorus atom, steric hindrance and leaving group specificity were reinforced as important determinants of inhibition activity.

Key words: Carbacylamidophosphate, AChE, BuChE

\section{Introduction}

Acetylcholinesterase (AChE) is of interest to enzymologists because of its critical role in neurotransmission and its high catalytic power (Quinn, 1987; Kovach, 1988; Taylor and Radic, 1994). It is readily phosphorylated at the active serine site by a variety of organophosphorus compounds which are mainly used as insecticides (Aldrich and Reiner, 1972; Taylor, 1990). Phosphorylation of acetylcholinesterase leads to the formation of stable covalent conjugates depending on the structure of the inhibitor and the particular enzyme studied (Ordentlich et al., 1993; Haux et al., 2000). Butyrylcholinesterase (BuChE) is very similar in structure and catalytic function to acetylcho- linesterase, but have a less well-defined role in biological processes (Taylor and Radic, 1994; Massoulie et al., 1993). The differences in the sensitivity of AChE from different species to in vitro inhibition by organophosphorus agents have been documented in numerous comparative studies (Chattopadhyay et al., 1986; Johnson and Wallace, 1987; Kemp and Wallace, 1990). The chemistry of organophosphorus inhibition of AChE is well established and provides a framework for investigating species differences in the molecular properties associated with enzyme inactivation. The inhibitors associate with AChE via Coulombic forces between the electron-defection phosphorus atom and a nucleophilic centre within the esteratic subsite of the enzyme. The formation of this reversi- 
ble complex, as reflected by the dissociation constant $\left(K_{\mathrm{D}}\right)$, is limited by steric hinderance possibly reflecting the finite dimensions of the esteratic subsite of AChE (Anderson et al., 1977; Mundy et al., 1978). Once formed, the complex undergoes rapid nucleophilic substitution wherein the enzyme becomes irreversibly phosphorylated at its nucleophilic centre, releasing the leaving group of the respective inhibitor. The electronic properties of the phosphorus atom in distinguishing among the inhibitor potency of dissimilar organophosphorus agents are well documented (Darlington et al., 1971; Hansch and Deutsch, 1966). Structureactivity correlations have been employed to establish the principal chemical properties responsible for discriminating between different organophosphorus inhibitors (Metcalf and Frederickson, 1965).

In our previous studies we discussed the synthesis, characterization, hydrolysis, and inhibition potency on human erythrocyte AChE activity of four carbacylamidophosphates with the general formula $\mathrm{RC}(\mathrm{O}) \mathrm{NHP}(\mathrm{O}) \mathrm{Cl}_{2}$, and constituted organophosphorus compounds with $\mathrm{R}=\mathrm{CCl}_{3}(\mathbf{1}), \mathrm{CHCl}_{2}$ (2), $\mathrm{CH}_{2} \mathrm{Cl}(3)$ and $\mathrm{CF}_{3}$ (4). Based on spectroscopic data and hydrophobicity evaluation we considered the electronic properties of the phosphorus atom and the hydrophobicity of the surrounding substituents on the hydrolysis tendency and the inhibitory potency of the selected compounds (Gholivand et al., 2006).

Since the differences in the inhibition potency of organophosphorus agents are a manifestation of differing molecular properties of the inhibitors involved in the interaction with the active site of

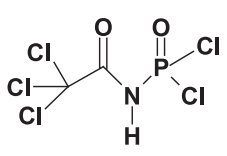

1

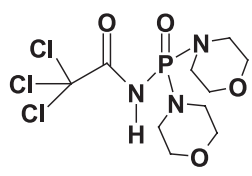

5

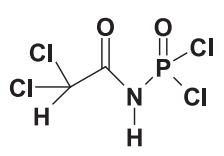

2

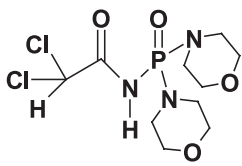

6 an enzyme, we were interested in studing the inhibition potency of four new synthesized carbacylamidophosphates (Gholivand et al., 2007) with the general formula $\mathrm{RC}(\mathrm{O}) \mathrm{NHP}(\mathrm{O})\left(\mathrm{R}^{\prime}\right)_{2}$, where $\mathrm{R}^{\prime}=$ morpholine and $\mathrm{R}=\mathrm{CCl}_{3}(\mathbf{5}), \mathrm{CHCl}_{2}(\mathbf{6}), \mathrm{CH}_{2} \mathrm{Cl}$ (7), $\mathrm{CF}_{3}(\mathbf{8})$, on $\mathrm{AChE}$ and $\mathrm{BuChE}$ activities and in comparing them with the inhibition activity of compounds 1-4 (Fig. 1). In addition, in vitro activities of $\mathbf{1 - 8}$ on BuChE and $\mathrm{AChE}$ and their kinetic parameters, inhibitory potency $\left(\mathrm{IC}_{50}\right)$, bimolecular rate constants $\left(K_{\mathrm{i}}\right)$, dissociation constant $\left(K_{\mathrm{D}}\right)$ and phosphorlation constant $\left(k_{\mathrm{p}}\right)$, were determined. Besides, in vivo $\mathrm{IC}_{50}$ inhibition potency of compounds 2 and $\mathbf{6}$, the most potent inhibitors, on $\mathrm{AChE}$ and BuChE activity and their acute toxicity $\left(\mathrm{LD}_{50}\right)$ were studied.

\section{Materials and Methods}

\section{Chemicals}

All syntheses of compounds $\mathbf{1 - 8}$ based on published methods (Gholivand et al., 2006, 2007) and were carried out under an argon atmosphere. Purified human plasma AChE $(3.1 .1 .7 ; 50$ units/785 $\mu \mathrm{l})$, purified horse plasma BuChE (lyophilized) from Sigma-Aldrich (UK), butyrylthiocholine (BuTCh) iodide, acetylthiocholine (ATCh) iodide, and 5, 4'-dithio-bis(2-nitrobenzoic acid) (DTNB) from Fluka (Tehran, Iran) were used. All other chemicals and solvents were purchased from Merck (Tehran, Iran).

\section{AChE activity assay}

The activity of AChE was determined by a modified Ellman method (Ellman et al., 1961): The

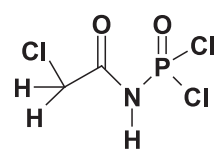

3

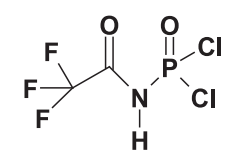

4

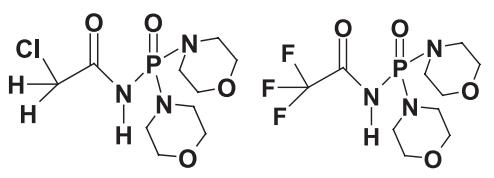

7

8

Fig. 1. Structures of compounds $\mathbf{1}-\mathbf{8}$. 
level of ATCh hydrolysis was monitored by liberated thiocholine which reacted with DTNB. Reactions were carried out at $37^{\circ} \mathrm{C}$ in $70 \mathrm{~mm}$ phosphate buffer $\left(\mathrm{Na}_{2} \mathrm{HPO}_{4} / \mathrm{NaH}_{2} \mathrm{PO}_{4}, \mathrm{pH} 7.4,920 \mu \mathrm{l}\right)$ containing the enzyme (diluted 100 times in phosphate buffer, pH 7.4), DTNB (0.1 mm final concentration, $50 \mu \mathrm{l})$, and ATCh $(0.135 \mathrm{~mm}$ final concentration, $15 \mu \mathrm{l})$. The absorbance change at $37^{\circ} \mathrm{C}$ was monitored with a spectrophotometer at $412 \mathrm{~nm}$ for $3 \mathrm{~min}$ and three replicates were run in each experiment. In the absence of inhibitors, the absorbance change was directly proportional to the enzyme level.

\section{BuChE activity assay}

The activity of BuChE was determined as the AChE activity by measuring thiocholine which reacted with DTNB after hydrolysis of BuTCh. The lyophilized BuChE was diluted with $100 \mathrm{~mm}$ phosphate buffer $(\mathrm{pH} 8)$ for the activity assay.

\section{AChE and BuChE inhibition}

The reaction mixtures for the determination of $\mathrm{IC}_{50}$ values of human erythrocyte $\mathrm{AChE}$ consisted of a DTNB solution $(5 \mu \mathrm{l})$, inhibitors $(4.5,9.5,25$, 47, 62 and $72 \mu \mathrm{l})$, ATCh iodide solution $(10 \mu \mathrm{l})$, and phosphate buffer ( $\mathrm{pH}$ 7.4) in a final volume of $100 \mu \mathrm{l}$. The final concentrations of DTNB and ATCh were $10^{-4}$ and $2.7 \cdot 10^{-5}$ M. The initial concentrations of inhibitors in ethanol were $3.57 \cdot 10^{-5}$, $4.08 \cdot 10^{-5}, \quad 4.76 \cdot 10^{-5}, \quad 4.38 \cdot 10^{-5}, \quad 2.62 \cdot 10^{-5}$, $2.89 \cdot 10^{-5}, 3.21 \cdot 10^{-5}$, and $3.02 \cdot 10^{-5} \mathrm{M}$, respectively. The enzyme concentration in the assay was $1.004 \cdot 10^{-10} \mathrm{M}$. The reaction mixtures for the $\mathrm{IC}_{50}$ values determination of $\mathrm{BuChE}$ were the same as in the AChE assay but the volumes of inhibitors were $5.4,10.5,28,48,65$, and $76 \mu \mathrm{l}$. The candidate inhibitors were incubated with the enzyme (AChE or BuChE), inhibitors, and DTNB for 5-10 min at $37^{\circ} \mathrm{C}$ prior to the addition of ATCh or BuTCh for the residual activity assay. The samples were placed in 96-well ELISA dishes (Nunc, Denmark) and the results were obtained by placing the 96well dishes into an ELISA plate reader (Stat-Fax 303 plus, Awareness Technology Inc, Palm City, FL, USA) at $412 \mathrm{~nm}$. The data were collected every $4 \mathrm{~min}$ for $24 \mathrm{~min}$.

\section{Calculation of hydrophobicity}

Calculated hydrophobicity extent, $\log P$, of the eight synthesized compounds was performed using the software $\log P$ (ChemDraw Ultra, 8. 0.3, 2003).

\section{Animals}

NMRI albino mice, weighing 20-25 g, were obtained from Pharmaceutical Sciences Research Center (PSRC) of Tehran University of Medical Sciences (TUMS), Tehran, Iran. The animals were all individually housed in plastic cages in an airconditioned room with controlled temperature $\left(20-22^{\circ} \mathrm{C}\right)$, automatic lighting and free access to standard laboratory diet and water. Animals were maintained under this conditions for $10 \mathrm{~d}$ prior to the experiment. They were randomly divided into three groups consisting of four mice each. Regarding the in vitro inhibitory concentration $\left(\mathrm{IC}_{50}\right)$ of paraoxon in human erythrocytes $[(4.7 \pm 0.9) \mu \mathrm{M}]$ (Gupta, 2006) as the reference compound, the equimolar dose and two upper and lower doses of compounds 2 and $\mathbf{6}$ in an 1.5 order were used in mice. Therefore, animals from group one to three received doses of $7.05,4.7$ and $3.13 \mu \mathrm{m}$ equal to $1.72,1.15$, and $0.76 \mathrm{mg} / \mathrm{kg}$ of compounds 2 and $\mathbf{6}$ as the most potent inhibitors, by gavage.

\section{AChE activity in erythrocytes}

The rate of hydrolysis of ATCh iodide in the suspension of erythrocytes ( $\mathrm{pH} \mathrm{7.6)}$ in the presence of benzethonium chloride was determined by measuring the maximum absorbance at $440 \mathrm{~nm}$ with a double beam spectrophotometer. In this test, the reaction of thiocholine iodide with DTNB gives a yellow 5-thio-2-nitrobenzoate anion. The enzyme activity was expressed as KU/l (George and Abernethy, 1983).

\section{BuChE activity in plasma}

$10 \mu \mathrm{l}$ of plasma sample were added to each duplicate tube, containing $3 \mathrm{ml}$ of $25 \mathrm{~nm}$ DTNB in $75 \mathrm{~mm}$ phosphate buffer. Then $10 \mu \mathrm{l}$ of $3 \mathrm{~mm}$ BuTCh iodide were added to the sample tube, and the change in the absorbance was measured at $412 \mathrm{~nm}$ using a double beam spectrophotometer (Ellman et al., 1961).

\section{Determination of toxicity $\left(L D_{50}\right)$}

In order to determine the acute toxicity $\left(\mathrm{LD}_{50}\right)$ of compounds $\mathbf{2}$ and $\mathbf{6}$, various doses [100, 300, 
$600,1000,1500$, and $2000 \mathrm{mg} /(\mathrm{kg} \cdot$ day $)]$ were gavaged to NMRI albino mice in separate groups of 4 each. The animals were observed for $48 \mathrm{~h}$ and any mortality was recorded at the end of this period. The $\mathrm{LD}_{50}$ value was determined by regression probit using Stats Direct (Chan and Hayes, 1989).

\section{Results}

The derivation of the kinetic values is based on the works of Kitz and Wilson (1962) and Segel (1975). The reaction describing the inhibition process and the definition of the kinetic parameters is based on the following scheme:

$$
[\mathrm{E}]+[\mathrm{I}] \underset{k_{-1}}{\stackrel{k_{1}}{\rightleftarrows}}[\mathrm{EI}]_{\mathrm{R}} \stackrel{k_{\mathrm{p}}}{\longrightarrow}[\mathrm{EI}]_{\mathrm{I}},
$$

where $[\mathrm{E}]$ and $[\mathrm{I}]$ represent the concentration of free enzyme and inhibitor, respectively, $[\mathrm{EI}]_{\mathrm{R}}$ is the reversible enzyme-inhibitor complex, and $[\mathrm{EI}]_{\mathrm{I}}$ the irreversibly phosphorylated enzyme-inhibitor complex; $k_{\mathrm{p}}$ is the rate constant of AChE phosphorylation and $K_{\mathrm{i}}$ the bimolecular inhibition constant with

$$
K_{\mathrm{m}}=k_{-1}+k_{\mathrm{p}} / k_{1} \text {. }
$$

Assuming that $k_{\mathrm{p}}>>k_{-1}$, then

$$
\begin{aligned}
& K_{\mathrm{m}}=k_{-1} / k_{1}=K_{\mathrm{D}}=1 / K_{\mathrm{A}}, \\
& K_{\mathrm{eq}}=k_{1} k_{\mathrm{p}} / k_{-1}=k_{\mathrm{p}} / K_{\mathrm{D}}=K_{\mathrm{A}} \times k_{\mathrm{P}}=K_{\mathrm{i}},
\end{aligned}
$$

where $K_{\mathrm{A}}$ is the association constant and $K_{\mathrm{D}}$ the dissociation constant.

The fraction of AChE activity remaining at time $t$ was calculated by dividing the remaining AChE activity by the original uninhibited enzyme activity $\left([\mathrm{EI}]_{\mathrm{t}} /[\mathrm{EI}]_{\mathrm{o}}\right)$. Least squares linear regression $(\ln )$ of the fraction of remaining AChE activity $\left([\mathrm{EI}]_{\mathrm{t}} /\right.$ $[\mathrm{EI}]_{\mathrm{o}}$ ) versus time (in min) resulted in a line at each inhibitor concentration with the slope $-k_{\text {app }}$

A

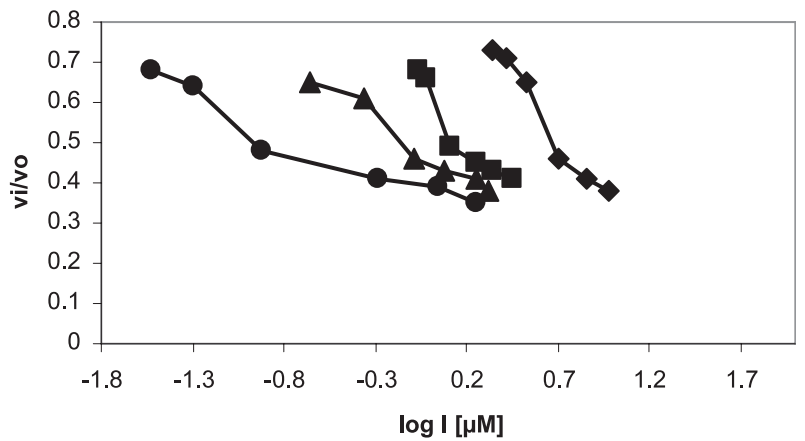

B

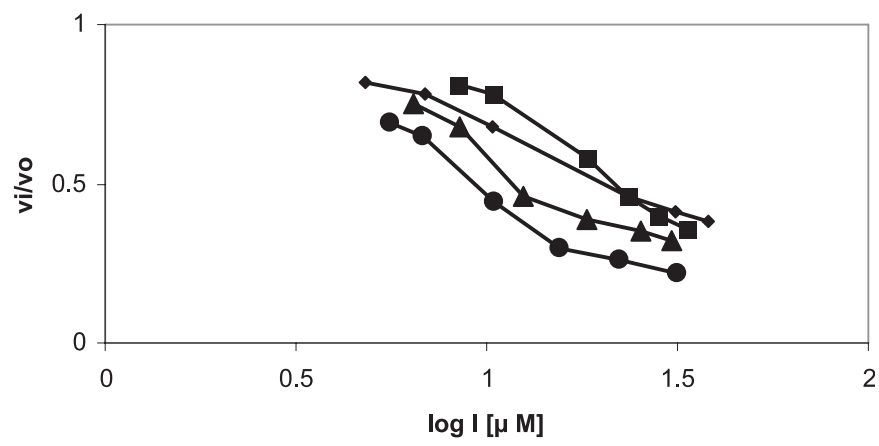

$\rightarrow-1 \rightarrow-2 \rightarrow-3 \rightarrow-4$

Fig. 2. Plot of $v_{\mathrm{i}} / v_{\mathrm{o}}$ against $\log [\mathrm{I}]$ of human erythrocyte $\mathrm{AChE}(\mathrm{A})$ and of BuChE (B) for inhibitors $\mathbf{1}-\mathbf{4}$. $v_{\mathrm{i}}$ and $v_{\mathrm{o}}$ are the activity of enzyme in the presence and absence of inhibitor, respectively, and [I] is the inhibitor concentration (in $\mu \mathrm{M}$ ). 
$\mathrm{C}$

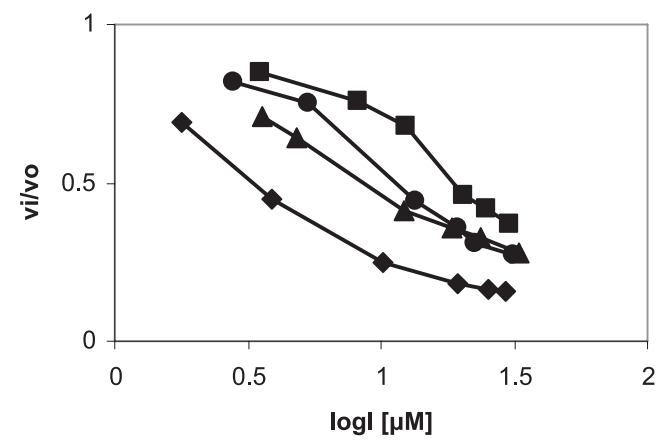

$\mathrm{D}$

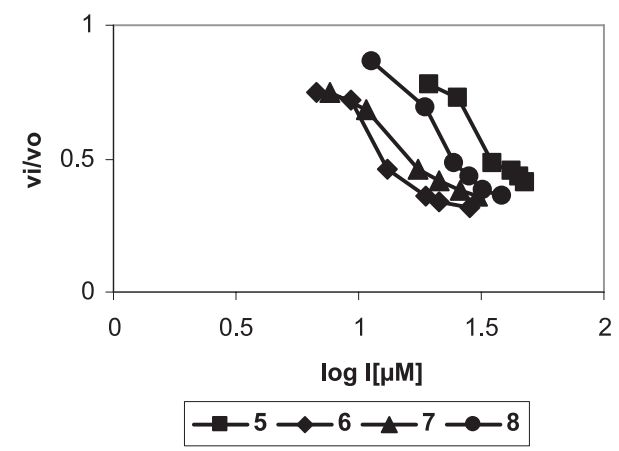

Fig. 3. Plot of $v_{\mathrm{i}} / v_{\mathrm{o}}$ against $\log [\mathrm{I}]$ of human erythrocyte $\mathrm{AChE}(\mathrm{C})$ and of BuChE (D) for inhibitors 5-8. $v_{\mathrm{i}}$ and $v_{\mathrm{O}}$ are the activity of enzyme in the presence and absence of inhibitor, respectively, and [I] is the inhibitor concentration (in $\mu \mathrm{M}$ ).

(the apparent rate of AChE inhibitor phosphorylation). A double reciprocal plot of the inhibitor concentration versus $k_{\text {app }}$ resulted in a line with slope $=1 / K_{\mathfrak{i}}, y$-intercept $=1 / k_{\mathrm{p}}$ and $x$-intercept $=$ $-1 / K_{\mathrm{D}}=-K_{\mathrm{A}}$ (Kitz and Wilson, 1962).
The in vitro inhibition of $\mathrm{AChE}$ and $\mathrm{BuChE}$ for compounds 1-4 are presented in Fig. 2. Fig 3 represents the in vitro inhibition of $\mathrm{AChE}$ and $\mathrm{Bu}$ $\mathrm{ChE}$ for compounds 5-8, and the $\mathrm{IC}_{50}$ values are included in Table I. The data demonstrate that compound 2 from compound series 1-4 and compound $\mathbf{6}$ from compound series of 5-8 were the most sensitive as $\mathrm{AChE}$ and $\mathrm{BuChE}$ inhibitors. By comparing the $\mathrm{IC}_{50}$ values of these 8 compounds, it is clear that the inhibition potency of these compounds in AChE was nearly 2- to 100-fold higher than the BuChE inhibition. Furthermore, compounds 1-4 had a stronger inhibitory effect on both $\mathrm{AChE}$ and BuChE than compounds 5-8. A representative set of data for determining $k_{\text {app }}$ at six concentrations of compound $\mathbf{6}$ is presented in Fig. 4. Least squares linear regression of the data at each inhibitor concentration resulted in a line having the slope $-k_{\text {app }}$ with regression coefficients between 0.98 to 0.99 . As the concentration of compound 6 increased, the slope increased, resulting in larger $k_{\text {app }}$ values. A double reciprocal plot of the concentration of compound $\mathbf{6}$ versus the $k_{\text {app }}$ values from Fig. 3 resulted in a line with slope = $1 / K_{\mathrm{i}}, y$-intercept $=1 / k_{\mathrm{p}}$ and $x$-intercept $=-1 /$ $K_{\mathrm{D}}=-K_{\mathrm{A}}$ and regression coefficients between 0.98 to 0.99 (Fig. 5). The mean $K_{\mathrm{i}}, k_{\mathrm{p}}, K_{\mathrm{A}}$ and $K_{\mathrm{D}}$ values for all eight compounds were calculated for $\mathrm{AChE}$ and BuChE and are summarized in Table I. These data suggest that the inhibition of $\mathrm{AChE}$ and $\mathrm{BuChE}$ follows a pseudo-first-order Michaelis-Menten process. Comparison of the kinetics $\left(\mathrm{IC}_{50}, K_{\mathrm{i}}, k_{\mathrm{p}}, K_{\mathrm{A}}\right.$ and $\left.K_{\mathrm{D}}\right)$ of $\mathrm{AChE}$ and $\mathrm{BuChE}$ inactivation by these eight compounds resulted in no significant difference for the measured variables except for compounds $\mathbf{2}$ and $\mathbf{6}$, which ap-

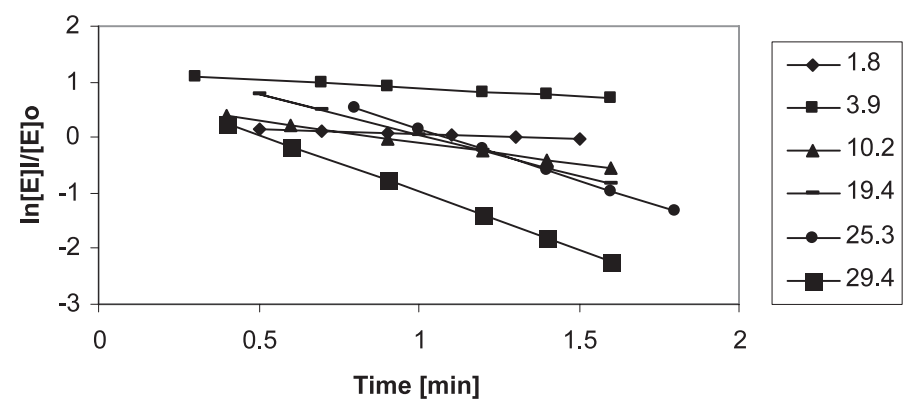

Fig. 4. A representative set of data for determining $-k_{\mathrm{app}}$ at six concentrations of 6 for human erythrocyte AChE. The time of incubation was variable for each inhibitor concentration and the slope of the lines $\left(-k_{\text {app }}\right)$ increased with increasing inhibitor concentration. Compound 6 concentrations were: 1.8, 3.9, 10.2, 19.4, 25.3, and 29.4 $\mu \mathrm{M}$. 
Table I. Kinetics of acetylcholinesterase inactivation by compounds $\mathbf{1}-\mathbf{4}$ (A) and $\mathbf{5}-\mathbf{8}$ (B), respectively, and kinetics of butyrylcholinesterase inactivation by compounds $\mathbf{1}-\mathbf{4}(\mathrm{C})$ and $\mathbf{5 - 8}(\mathrm{D})$, respectively.

A

\begin{tabular}{|c|c|c|c|c|c|}
\hline Compound & $\begin{array}{l}\mathrm{IC}_{50} \\
{[\mu \mathrm{M}]}\end{array}$ & $\begin{array}{c}K_{\mathrm{i}} \\
{[\mathrm{mmol} \mathrm{min}]^{-1}}\end{array}$ & $\begin{array}{c}k_{\mathrm{p}} \\
{\left[\min ^{-1}\right]}\end{array}$ & $\begin{array}{c}K_{\mathrm{A}} \\
{\left[\mathrm{mM}^{-1}\right]}\end{array}$ & $\begin{array}{c}K_{\mathrm{D}} \\
{[\mu \mathrm{M}]}\end{array}$ \\
\hline 1 & $3.8 \pm 0.4^{\mathrm{a}}$ & $140 \pm 20$ & $10.92 \pm 2.4$ & $17.1 \pm 3.1$ & $75.8 \pm 4.38$ \\
\hline 2 & $0.052 \pm 0.02$ & $980 \pm 40$ & $47.8 \pm 13.6$ & $38.1 \pm 10.7$ & $41.2 \pm 4.71$ \\
\hline 3 & $0.63 \pm 0.12$ & $760 \pm 30$ & $37.7 \pm 9.3$ & $31 \pm 5.3$ & $48.6 \pm 9.69$ \\
\hline 4 & $2.4 \pm 1.19$ & $450 \pm 40$ & $23.4 \pm 3.6$ & $27 \pm 6.6$ & $52.3 \pm 3.28$ \\
\hline
\end{tabular}

B

\begin{tabular}{lccccc}
\hline Compound & $\begin{array}{c}\mathrm{IC}_{50} \\
{[\mu \mathrm{M}]}\end{array}$ & $\begin{array}{c}K_{\mathrm{i}} \\
{[\mathrm{mmol} \mathrm{min}]^{-1}}\end{array}$ & $\begin{array}{c}k_{\mathrm{p}} \\
{\left[\mathrm{min}^{-1}\right]}\end{array}$ & $\begin{array}{c}K_{\mathrm{A}} \\
{\left[\mathrm{mm}^{-1}\right]}\end{array}$ & $\begin{array}{c}K_{\mathrm{D}} \\
{[\mu \mathrm{M}]}\end{array}$ \\
\hline $\mathbf{5}$ & $27.7 \pm 8.2^{\mathrm{a}}$ & $20.4 \pm 9.7$ & $5.83 \pm 1.5$ & $3.5 \pm 1.04$ & $452.6 \pm 46.1$ \\
$\mathbf{6}$ & $3.15 \pm 0.85$ & $93 \pm 11$ & $18.8 \pm 3.4$ & $6.8 \pm 1.48$ & $195.6 \pm 7.64$ \\
$\mathbf{7}$ & $5.81 \pm 0.61$ & $78 \pm 13$ & $10.9 \pm 2.6$ & $5.2 \pm 0.4$ & $223.8 \pm 15.9$ \\
$\mathbf{8}$ & $15.4 \pm 3.8$ & $46 \pm 14$ & $12.9 \pm 2.3$ & $4.2 \pm 1.1$ & $368.2 \pm 35.9$ \\
\hline
\end{tabular}

$\mathrm{C}$

\begin{tabular}{lccccc}
\hline Compound & $\begin{array}{c}\mathrm{IC}_{50} \\
{[\mu \mathrm{M}]}\end{array}$ & $\begin{array}{c}K_{\mathrm{i}} \\
{[\mathrm{mmol} \mathrm{min}]^{-1}}\end{array}$ & $\begin{array}{c}k_{\mathrm{p}} \\
{\left[\mathrm{min}^{-1}\right]}\end{array}$ & $\begin{array}{c}K_{\mathrm{A}} \\
{\left[\mathrm{mM}^{-1}\right]}\end{array}$ & $\begin{array}{c}K_{\mathrm{D}} \\
{[\mu \mathrm{M}]}\end{array}$ \\
\hline $\mathbf{1}$ & $30.5 \pm 5.3^{\mathrm{a}}$ & $1.8 \pm 0.3$ & $4.4 \pm 1.1$ & $0.55 \pm 0.01$ & $2228.3 \pm 11$ \\
$\mathbf{2}$ & $7.3 \pm 1.6$ & $9.8 \pm 0.6$ & $16.4 \pm 2.1$ & $0.752 \pm 0.11$ & $1623.2 \pm 67.7$ \\
$\mathbf{3}$ & $13.1 \pm 1.9$ & $8.2 \pm 0.9$ & $13.3 \pm 1.9$ & $0.68 \pm 0.076$ & $1723 \pm 67.4$ \\
$\mathbf{4}$ & $22 \pm 2.6$ & $6.2 \pm 0.6$ & $11.5 \pm 1.4$ & $0.592 \pm 0.04$ & $1862 \pm 57$ \\
\hline
\end{tabular}

$\mathrm{D}$

\begin{tabular}{lccrrc}
\hline Compound & $\begin{array}{c}\mathrm{IC}_{50} \\
{[\mu \mathrm{M}]}\end{array}$ & $\begin{array}{c}K_{\mathrm{i}} \\
{[\mathrm{mmol} \mathrm{min}]^{-1}}\end{array}$ & $\begin{array}{c}k_{\mathrm{p}} \\
{\left[\mathrm{min}^{-1}\right]}\end{array}$ & $\begin{array}{c}K_{\mathrm{A}} \\
{\left[\mathrm{mM}^{-1}\right]}\end{array}$ & $\begin{array}{c}K_{\mathrm{D}} \\
{[\mu \mathrm{M}]}\end{array}$ \\
\hline $\mathbf{5}$ & $49.4 \pm 14.3^{\mathrm{a}}$ & $0.14 \pm 0.03$ & $2.1 \pm 0.7$ & $0.046 \pm 0.006$ & $25635.2 \pm 194.2$ \\
$\mathbf{6}$ & $13.7 \pm 1.2$ & $0.82 \pm 0.04$ & $12.3 \pm 1.1$ & $0.074 \pm 0.005$ & $14832.2 \pm 339.5$ \\
$\mathbf{7}$ & $17.9 \pm 1.3$ & $0.68 \pm 0.064$ & $10.2 \pm 0.7$ & $0.079 \pm 0.015$ & $15823.1 \pm 198.1$ \\
$\mathbf{8}$ & $25.1 \pm 1.9$ & $0.46 \pm 0.08$ & $7.6 \pm 1.1$ & $0.062 \pm 0.004$ & $17352.3 \pm 110.9$ \\
\hline
\end{tabular}

a Values represent the means \pm SD of three individual parameter determinations.

Table II. Data resulted from in vivo experiments.

\begin{tabular}{lccc}
\hline Compound & $\begin{array}{c}\mathrm{LD}_{50} \\
{[\mathrm{mg} / \mathrm{kg}]}\end{array}$ & $\begin{array}{c}\mathrm{AChE} \mathrm{IC}_{50} \\
{[\mu \mathrm{M}]}\end{array}$ & $\begin{array}{c}\text { BuChE } \mathrm{IC}_{50} \\
{[\mu \mathrm{M}]}\end{array}$ \\
\hline $\mathbf{2}$ & $125 \pm 12.2^{\mathrm{a}}$ & $110 \pm 8.2$ & $1096 \pm 14.3$ \\
$\mathbf{6}$ & $190 \pm 14.7$ & $375 \pm 11.6$ & $1263 \pm 21.2$ \\
\hline
\end{tabular}

a Values represent the means \pm SD of three individual parameter determinations.

peared to be more sensitive to $\mathrm{AChE}$ and $\mathrm{BuChE}$ expressed by the significantly greater $k_{\mathrm{p}}$ and $K_{\mathrm{i}}$ values and the lower $\mathrm{IC}_{50}$ values.

As shown in Table I, parts A and C, the AChE $\mathrm{IC}_{50}$ value of compound $\mathbf{2}$ is nearly 12 - to 70 -fold greater than of compounds $\mathbf{1}, \mathbf{3}$, and $\mathbf{4}$. Also, comparison between the $\mathrm{AChE} \mathrm{IC}_{50}$ values of compound 6 with 5,7 , and 8 shows the smaller difference ranges, from 2- to 9-fold, in inhibition activity.

These differences are also evident from the nearly 5- to 7-fold greater $K_{\mathrm{i}}$ values for compounds 2 and 6 relative to the other compounds, which result in both larger phosphorylation rate constants $\left(k_{\mathrm{p}}\right)$ and $K_{\mathrm{A}}$ values.

The acute toxicity experiment $\left(\mathrm{LD}_{50}\right)$ demonstrated that compounds $\mathbf{2}$ and $\mathbf{6}$ are lethal up to a dose of $<600 \mathrm{mg} / \mathrm{kg}$ after oral administration (Table II). Treatment with the compounds 2 and $\mathbf{6}$ by doses of $<100 \mathrm{mg} /(\mathrm{kg} \cdot$ day $)$ inhibited both AChE activity in erythrocytes and BuChE activity in 


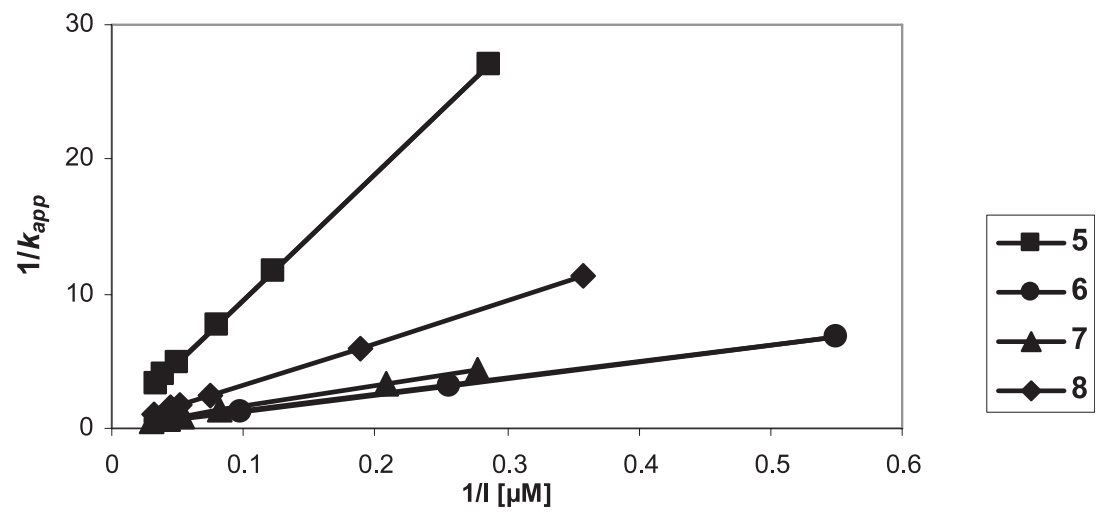

Fig. 5. A representative double reciprocal plot of inhibitor concentrations versus $k_{\mathrm{app}}$. Linear regression of six points representing $k_{\text {app }}$ at six inhibitor concentrations for each inhibitor resulted in a line with slope $1 / K_{\mathrm{i}}, y$-intercept $=$ $1 / k_{\mathrm{p}}$, and $x$-intercept $=-1 / K_{\mathrm{D}}=-K_{\mathrm{A}}$.

\begin{tabular}{lcccccc}
\hline Compound & $\begin{array}{c}M_{\mathrm{W}} \\
{[\mathrm{g} / \mathrm{mol}]}\end{array}$ & $\operatorname{Clog} P$ & $\begin{array}{c}\delta\left({ }^{31} \mathrm{P}\right) \\
(\mathrm{ppm})\end{array}$ & $\begin{array}{c}(\mathrm{P}=\mathrm{O}) \\
{\left[\mathrm{cm}^{-1}\right]}\end{array}$ & $\begin{array}{c}v(\mathrm{P}-\mathrm{Cl}) \\
{\left[\mathrm{cm}^{-1}\right]}\end{array}$ & $\begin{array}{c}v\left(\mathrm{P}-\mathrm{N}_{\text {amine }}\right) \\
{\left[\mathrm{cm}^{-1}\right]}\end{array}$ \\
\hline $\mathbf{1}$ & 279.3 & 0.397 & 8.08 & 1181 & 590 & - \\
$\mathbf{2}$ & 244.8 & -0.306 & 8.20 & 1194 & 580 & - \\
$\mathbf{3}$ & 210.4 & -1.36 & 6.62 & 1125 & 585 & - \\
$\mathbf{4}$ & 229.9 & -0.923 & 7.42 & 1180 & 593 & - \\
$\mathbf{5}$ & 380.6 & 2.917 & 9.51 & 1197 & - & 1108 \\
$\mathbf{6}$ & 346.1 & 2.214 & 9.58 & 1199 & - & 1106 \\
$\mathbf{7}$ & 311.5 & 1.151 & 8.39 & 1173 & - & 1108 \\
$\mathbf{8}$ & 331 & 1.597 & 8.44 & 1193 & - & 1094 \\
\hline
\end{tabular}

Table III. IR, $\delta\left({ }^{31} \mathrm{P}\right)$ and calculated hydrophobicity data for compounds $\mathbf{1}$ to $\mathbf{8}$. plasma (Table II). Compound $\mathbf{2}$ had a higher inhibition activity in $\mathrm{AChE}\left(\mathrm{IC}_{50}=110 \mu \mathrm{M}\right)$ than compound 6.

\section{Discussion}

The initial alteration at the active site of the enzyme may involve local changes in the peptide conformation and charge or steric repulsion imposed by the phosphoryl group. Structure-activity correlations have been employed to establish the principal chemical properties responsible for discriminating between different organophosphorus inhibitors (Metcalf and Frederickson, 1965). The inhibition process is dependent upon the reactivity, stereochemistry and leaving group in organophosphorus compounds (Thompson et al., 1996). The importance of the electropositivity of the phosphorus atom in the Coulombic association of the inhibitors with $\mathrm{AChE}$ is well known. As we discussed in our previous work (Gholivand et al., 2006) and according to data presented in Table III, ${ }^{31} \mathrm{P}$ chemical shifts for the synthesized compounds revealed that the phosphorus atom in compounds $\mathbf{1 - 4}$ has less electropositivity than in compounds 5-8. Comparing the infrared vibrational frequencies for the $\mathrm{P}=\mathrm{O}$ bond demonstrated that this bond is tighter in compounds 5-8 than in $\mathbf{1 - 4}$. It might be expected that the inhibition potency of compounds 5-8 should be larger than of 1-4. Conversely, as shown in Table I, parts $\mathrm{A}$ and $\mathrm{C}$, the $\mathrm{IC}_{50}$ values of the above mentioned compounds are nearly 7 - to 60 -fold less than of compounds 1-4. It can be resulted that some other structural factors affect the inhibition potency of these organophosphorus compounds on AChE. Steric exclusion of bulky inhibitors from the active site has been implicated as a major factor governing the inhibition of AChE (Fukuto et al., 1959). Consequently, it has been proposed that resistance to organophosphorus may be conferred, in part, by the limiting dimensions of the esteratic subsite of AChE (Kemp and Wallace, 1990). The calculated $\log P(\mathrm{O} / \mathrm{W})$ values as a measure of hydrophobicity for all eight synthesized inhibitors are pre- 
sented in Table III. Despite the fact that the heterocyclic ring, morpholine, in compounds 5-8 adopts a chair conformation as the most stable conformer, similar to that of cyclohexane, to relieve steric strain, and is slightly flattened at the nitrogen and oxygen ends (Gholivand et al., 2007), the calculated $\log P(\mathrm{O} / \mathrm{W})$ values of these compounds are greater than those for compounds 1-4. By comparing the $\mathrm{IC}_{50}$ values of inhibitors for $\mathrm{AChE}$, it was demonstrated that compounds 5-8 with more hydrophobic character have less inhibition potency on AChE than compounds 1-4. It was revealed that, although the phosphorus atom of compounds 5-8 is more electropositive relative to compounds 1-4, hydrophobic subsistents hinder rather than enhance the association of organophosphorus with AChE. This can also be discussed by comparing the low affinity (large $K_{\mathrm{D}}$ ) of $\mathrm{AChE}$ to the inhibitors 5-8 relative to compounds $\mathbf{1 - 4}$.

To be a potent inhibitor of cholinesterase, an organophosphorus compound usually contains a good leaving group Z (Scheme 1), to form of a phosphoserine linkage (Thompson et al., 1996). Replacing the chlorine atoms in 1-4 with morpholine (compounds 5-8) resulted in a smaller inhibitory effect on AChE (Table I, parts A and C). The crystallographic data for compounds with morpholine groups (Gholivand et al., 2007) indicated that the $\mathrm{P}-\mathrm{N}_{\text {amine }}$ bond lengths are between 1.63$1.64 \AA$, which are shorter than a $\mathrm{P}-\mathrm{N}$ single bond $(1.77 \AA)$ and longer than a $\mathrm{P}=\mathrm{N}$ double bond (1.57 Å) (Thompson et al., 1996; Corbridge, 1995). As it is known, halogen atoms are good leaving groups; therefore the $\mathrm{P}-\mathrm{Cl}$ bond is more labile than the $\mathrm{P}-\mathrm{N}_{\text {amine }}$ bond. This leads to the easier formation of a phosphoserine linkage in the enzyme active site. In spite of the fact that replacing chlorine atoms with morpholine groups leads to more electropositivity of the phosphorus atom, increasing in hydrophobicity and bonding energy of the $\mathrm{P}-\mathrm{N}_{\text {amine }}$ bond are two important factors which make them unsuitable leaving groups and decrease the inhibitory potency of them on the AChE activity. The more inhibitory effect of com-

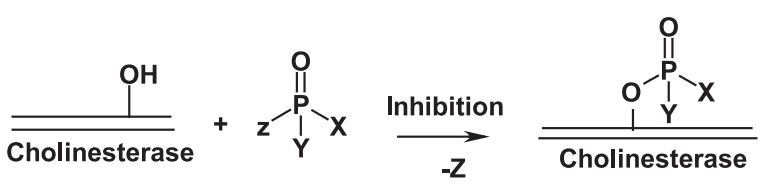

Scheme 1. Proposed mechanism for AChE and BuChE inhibition by organophosphorus compounds. pounds $\mathbf{2}$ and $\mathbf{6}$ on AChE, in spite of large hydrophobicity may be due to their more electropositive of phosphorus atom expressed by ${ }^{31} \mathrm{P}$ chemical shifts (Table III).

By comparing data of Table I, parts B and D with parts $\mathrm{A}$ and $\mathrm{C}$, it is clear that the inhibitory effects of 1-8 are nearly 2- to 100-fold higher on $\mathrm{AChE}$ than on BuChE. X-Ray structures of AChE from various sources showed that the catalytic site is located near the bottom of a deep and narrow "gorge" (Sussman et al., 1991; Kryger et al., 2000). One of the striking features of this gorge is related to the presence of 14 aromatic residues, which line about $40 \%$ of its surface and which are highly conserved in enzymes from different species (Axelsen et al., 1994). Yet, BuChE, another type of cholinesterase found in vertebrates, catalyzes acetylcholine hydrolysis as efficiently as AChE, although six of the active site gorge aromatic residues are replaced by aliphatic amino acids (Cygler et al., 1993). According to early hypothesis and modeling experiments (Jarv, 1984), the main functional differences between the $\mathrm{AChE}$ and $\mathrm{BuChE}$ active sites are related to the structure of the acyl pocket. Accordingly, BuChE is more reactive than $\mathrm{AChE}$ toward bulky substrates such as DFP or paraoxon as organophosphorus inhibitors. The latest results based mainly on determining the activity of AChE and $\mathrm{BuChE}$ toward certain stereoselective alkylphosphorates implying that active centres of $\mathrm{AChE}$ and BuChE may not be as similar as thought before (Ordentlich et al., 1999; Quistad et al., 2005). It is rather surprising to find that compounds 5-8 with more hydrophobicity due to morpholine bulky groups have nearly 2 -fold less $\mathrm{IC}_{50}$ values than compounds $\mathbf{1 - 4}$ (Table I, parts B and D).

The in vivo toxicological studies involve several aspects for the carbacylamidophosphates. Albino mice were used as a model for the in vivo study of AChE and BChE inhibition. This system has several advantages; firstly, Albino mice erythrocytes and plasma are a convenient $\mathrm{AChE}$ and $\mathrm{Bu}$ ChE source with high activity and sensitvitey to organophosphorus inhibitors. Secondly, in vivo inhibition of enzymatic activity correlates with poisoning signs and toxicity for carbacylamidophosphate. Due to these advantages, the in vivo AChE and $\mathrm{BuChE}$ activities of the most potent inhibitors $\mathbf{2}$ and $\mathbf{6}$ were determined, and the albino mice cholinesterase activity from control group and from 
the animals of the in vivo study after treatment for $24 \mathrm{~h}$ are shown in Table II.

The results demonstrate that the inhibitory potency of selected compounds was different depending on the enzyme source. It may be due to the different tertiary structure of the enzyme source or arises from the different structure of the inhibitors.

In addition, an in vitro study showed that new synthesized carbacylamidophosphates are moderate cholinesterase inhibitors, but an in vivo experiment indicated that they have weak inhibition activity. As carbacylamidophosphate compounds can react with a family of target and nontarget serine esterases and nontarget serine proteases, hydrolysis of these compounds by nontarget esterases and unknown limitation probably cause that these inhibitors have very weak inhibitory activity on cholinesterases in in vivo studies.

In summary, comparison of reactivity profiles of compounds $\mathbf{1 - 8}$ suggests that the molecules with the core unit $-\mathrm{C}(\mathrm{O}) \mathrm{NHPO}$ ) - are weak inhibitors

Aldrich W. N. and Reiner E. (1972), Enzyme Inhibitors as Substrates. Elsevier, Amsterdam, pp. 123-132.

Anderson R. A., Aaraas I., Gaare G., and Fonnum F. (1977), Inhibition of acetylcholinesterase from different species by organophosphorus compounds, carbamates and methylsulphonylfluoride. Gen. Pharmacol. 8, 331-334.

Axelsen P. H., Harel M., Silman I., and Sussman J. L. (1994), Structure and dynamics of the active site gorge of acetylcholinesterase: synergistic use of molecular dynamics simulation and X-ray crystallography. Protein Sci. 3, 188-197.

Chan P. K. and Hayes A. (1989), Principles and methods for acute toxicity and eye irritancy. In: Principles and Methods of Toxicology, 2nd ed. (Hayes A. W., ed.). Raven, New York, USA, pp. 169-220.

Chattopadhyay D. P., Dighe S. K., Nashikkar A. B., and Dube D. K. (1986), Species differences in the in vitro inhibition of brain acetylcholinesterase and carboxylesterase by mipafox, paraoxon, and soman. Pestic. Biochem. Physiol. 26, 202-208.

Corbridge D. E. C. (1995), Phosphorus, an Outline of its Chemistry, Biochemistry and Technology, $5^{\text {th }}$ ed. Elsevier, Amsterdam, The Netherlands.

Cygler M., Schrag J. D., Sussman J. L., Harel M., Silman I., Gentry M. K., and Doctor B. P. (1993), Relationship between sequence conservation and three-dimensional structure in a large family of esterases, lipases, and related proteins. Protein Sci. 2, 366-382.

Darlington W. A., Partos R. D., and Ratts K. W. (1971), Correlation of cholinesterase inhibition and toxicol- to both $\mathrm{AChE}$ and BuChE in comparison with strong inhibitors like paraoxon. The $\mathrm{IC}_{50}$ values of erythrocytes in $\mathrm{AChE}$ and the $\mathrm{LD}_{50}$ values in oral administration of compounds 2 and $\mathbf{6}$ demonstrated that paraoxon is nearly 70 -fold more toxic and a stronger inhibitor than 2 and 6. Also the results show that they are not proper inhibitors for acting with the active site of the $\mathrm{BuChE}$ relative to the AChE enzyme. Furthermore, the importance of electropositivity of phosphorus atom, steric hindrances and leaving group specificity are reinforced as important determinants of inhibition potency. However, the significance of each of these factors differs between compounds based on their chemical structures.

\section{Acknowledgement}

This study was supported by grants from Tarbiat Modarres University and Pharmaceutical Sciences Research Center of Tehran University of Medical Sciences. The authors wish to thank the help of Mr. Reza Khorasani in animal experiments. ogy in insects and mammals. I. Ethylphosphonates. Toxicol. Appl. Pharmacol. 18, 542-547.

Ellman G. L., Courtney K. D., Anders V. J., and Featherstone R. M. (1961), A new and rapid colorimetric determination of acetylcholinesterase activity. Biochem. Pharmacol. 7, 88-95.

Fukuto T. R., Metcalf R. L., and Winton R. L. (1959), Alkyl phosphonic acid esters as insecticides. J. Econ. Entomol. 52, 1121-1127.

George P. M. and Abernethy M. H. (1983), Improved Ellman procedure for RBC cholinesterase. Clin. Chem. 29, 365-368.

Gholivand K., Madani Alizadehgan A., Anaraki Firooz A., Khajeh K., Naderi-manesh H., and Bijanzadeh H. (2006), Anticholinesterase activity of some major intermediates in carbacylamidophosphates synthesis: preparation, spectral characterization and inhibition potency determination. J. Enz. Inhib. Med. Chem. 21, $105-111$.

Gholivand K., Mojahed F., and Madani Alizadehgan A. (2007), Synthesis and characterization of novel phosphoramidate derivatives with morpholine substituents: Crystal structure of $\left(\mathrm{CF}_{3}\right) \mathrm{C}(\mathrm{O}) \mathrm{NHP}(\mathrm{O})$ $\left(\mathrm{NC}_{4} \mathrm{H}_{8} \mathrm{O}\right)_{2}$ and $\left(p-\mathrm{Br}-\mathrm{C}_{6} \mathrm{H}_{4}\right) \mathrm{C}(\mathrm{O}) \mathrm{NHP}(\mathrm{O})\left(\mathrm{NC}_{4} \mathrm{H}_{8} \mathrm{O}\right)_{2}$. Polish J. Chem. 81, 393-402.

Gupta R. C. (2006), Toxicology of Organophosphates and Carbamate Compounds. Elsevier Academic Press, San Diego, pp. 14-15.

Hansch C. and Deutsch E. W. (1966), The use of substituent constants in the study of structure-activity relationships in cholinesterase inhibitors. Biochem. Biophys. Acta. 126, 117-128. 
Haux J. E., Quistad G. B., and Casida J. E. (2000), Phosphobutyrylcholinesterase, phosphorylation of the esteratic site of butyrylcholinesterease by ethephon [(2chloroethyl)phosphonic acid] dianion. Chem. Res. Toxicol. 13, 646-651C.

Jarv J. (1984), Stereochemical aspects of cholinesterase catalysis. Bioorg. Chem. 12, 259-278.

Johnson J. A. and Wallace K. B. (1987), Species-related differences in the inhibition of brain acetylcholinesterase by paraoxon and malaoxon. Toxicol. Appl. Pharmacol. 88, 234-241.

Kemp J. R. and Wallace K. B. (1990), Molecular determinants of the species-selective inhibition of brain acetylcholinesterase. Toxicol. Appl. Pharmacol. 104, 246-258.

Kitz R. and Wilson I. B. (1962), Esters of methanesulfuric acid as irreversible inhibitors of acetylcholinesterase. J. Biol. Chem. 237, 3245-3249.

Kovach I. M. (1988), Structure and dynamics of serine hydrolase-organophosphate adducts. J. Enzyme Inhib. Med. Chem. 2, 199-208.

Kryger G., Harel M., Giles K., Toker L., Velan B., Lazar A., Kronman C., Barak D., Ariel N., Shafferman A., Silman I., and Sussman J. L. (2000), Structures of recombinant native and E202Q mutant human acetylcholinesterase complexed with the snake-venom toxin fasciculin-II. Acta Crystallogr. D Biol. Crystallogr. 56, $1385-1394$.

Massoulie J., Pezzementi L., Bon S., Krejci E., and Vallette F. M. (1993), Molecular and cellular biology of cholinesterases. Prog. Neurobiol. 41, 31-91.

Metcalf R. L. and Frederickson M. (1965), Selective insecticidal action of isopropyl parathion and analogues. J. Econ. Entomol. 58, 143-147.

Mundy R. L., Bowman M. C., Farmer J. H., and Haley T. J. (1978), Quantitative structure activity study of a series of substituted $O, O$-dimethyl $O$-( $p$-nitrophenyl) phosphorothioates and $O$-analogs. Arch. Toxicol. 41, $111-123$.
Ordentlich A., Kronman C., Barak D., Stein D., Ariel N., Marcus D., Velan B., and Shafferman A. (1993), Engineering resistance to 'aging' of phosphorylated human acetylcholinesterase. Role of hydrogen bond network in the active center. FEBS Lett. 15, 215-220.

Ordentlich A., Barak D., Kronman C., Benschop H. P., De Jong L. P., Ariel N., Barak R., Segall Y., Velan B., and Shafferman A. (1999), Exploring the active center of human acetylcholinesterase with stereomers of an organophosphorus inhibitor with two chiral centers. Biochemistry 9, 3055-3066.

Quinn D. M. (1987), Acetylcholinesterase: enzyme structure, reaction dynamics, and virtual transition states. Chem. Rev. 87, 955-975.

Quistad G. B., Klintenberg R., and Casida J. E. (2005), Blood acyl peptide hydrolase activity is a sensitive mark for exposure to some organophosphate toxicants. Toxicol. Sci. 86, 291-299.

Segel I. H. (1975), Enzyme kinetics: Behavior and Analysis of Rapid Equilibrium and Steady-State Enzyme Systems. Wiley, New York.

Sussman J. L., Harel M., Frolow F., Oefner C., Goldman A., Toker L., and Silman I. (1991), Atomic structure of acetylcholinesterase from Torpedo californica: a prototypic acetylcholine-binding protein. Science $\mathbf{2 3}$, $872-879$.

Taylor P. (1990), In: The Pharmacological Basis of Therapeutics, $8^{\text {th }}$ ed. (Gilman A. G., Goddman L. S., Rall T. W., and Murad F., eds.). Macmillan Press, New York, pp. 131-149.

Taylor P. and Radic Z. (1994), The cholinesterases: from genes to proteins. Annu. Rev. Pharmacol. Toxicol. 34, $281-320$.

Thompson C. M., Suarez A. I., and Rodriguez O.P. (1996), Synthesis and ${ }^{31} \mathrm{P}$ chemical shift identification of tripeptide active site models that represent human serum acetylcholinesterase covalently modified at serine by certain organophosphates. Chem. Res. Toxicol. 9, $1325-1332$. 